\begin{tabular}{c} 
LOSARI: Jurnal Pengabdian Kepada Masyarakat \\
http://ojs.losari.or.id/index.php/losari \\
Volume 3 | Nomor 2 | Desember | 2021 \\
e-ISSN: 2684-8678 dan p-ISSN: 2684-9887 \\
\hline
\end{tabular}

\title{
Penyuluhan Kepada Warga Terkait Penanganan Pandemi COVID-19 di Beberapa Lingkungan di Villa Kalijudan Indah
}

\author{
Heristama Anugerah Putra ${ }^{1}$, Agustina Ivana Siswanto ${ }^{2}$, Fransiska Dena ${ }^{3}$, Angga Rezaldy \\ Kristyawan ${ }^{3}$, Putri Indah Novitalia ${ }^{3}$, Yosua Anggun Putra ${ }^{3}$
}

\author{
Keywords: \\ Pandemi, \\ Penyuluhan, \\ Vaksinasi, \\ Protokol, \\ Analisa sosial.

\section{Corespondensi Author} \\ ${ }^{1 *}$ Dosen Program Studi Arsitektur, \\ Universitas Katolik Darma Cendika \\ ${ }^{2}$ Mahasiswa Program Studi Teknik \\ Industri, Universitas Katolik Darma \\ Cendika \\ ${ }^{3}$ Mahasiswa Program Studi Akuntansi, \\ Universitas Katolik Darma Cendika \\ Jl. Dr. Ir. Soekarno No. 201 Surabaya \\ Email: heristama.putra@ukdc.ac.id
}

\begin{abstract}
Abstrak. Pandemi Covid-19 hingga saat ini masih menjadi musibah bagi seluruh umat manusia di seluruh dunia tak terkecuali di Indonesia. Peningkatan jumlah kasus positif dan meninggal dunia terus mengalami peningkatan. Kasus Covid-19 terbanyak terjadi di Pulau Jawa. Virus ini terus melakukan mutasi genetik menjadi virus yang mematikan. Mutasi virus berasal dari beberapa negara salah satunya dari India yang masuk ke Indonesia. Delta varian merupakan nama atau jenis virus Covid-19 tersebut. Kota Surabaya menjadi episentrum di provinsi Jawa Timur yang jumlah kasus positif dan meninggal dunianya cukup banyak. Setiap wilayah di Surabaya diwajibkan menerapkan protokol kesehatan yang sangat ketat dan dengan dikuatkan adanya waktu PPKM (Pemberlakuan Pembatasan Kegiatan Masyarakat) darurat. Tujuan dari terlaksananya kegiatan KKN yang dilakukan oleh beberapa mahasiswa UKDC di lingkungannya masing-masing yakni memberikan penyuluhan kepada warga setempat terkait penanganan pandemi Covid-19. Warga sekitar berharap agar virus Covid-19 ini dapat terhenti dengan segera dan tidak meluas secara berkelanjutan. Metode yang digunakan dalam kegiatan KKN ini yaitu analisa sosial. Pengamatan situasi menjadi poin utama dalam menentukan jenis kegiatan yang didasarkan dari kebutuhan warga setempat dalam penanganan pencegahan penyakit Covid-19. Hasil yang diharapkan dari kegiatan penyuluhan KKN ini, masyarakat mendapatkan edukasi akan pentingnya menjaga kebersihan dalam kehidupan sehari-hari. Edukasi ini berupa pemaparan oleh tim KKN ke seluruh warga yang tinggal di lingkungan Villa Kalijudan Indah. Selain itu tim pengabdian kepada masyarakat memberikan alat protokol kesehatan seperti masker dan handsanitizer serta poster dan stiker tanda bahwa anggota keluarga tersebut telah divaksin.
\end{abstract}




\section{Pendahuluan}

Penyebaran virus Covid-19 hingga saat ini masih belum berakhir terutama dibeberapa negara yang menjadi tempat mutasi virus tersebut. Vaksin sendiri sudah mulai banyak ditemukan dan telah dilakukan upaya vaksinasi di beberapa negara tidak terkecuali di Indonesia. Namun dengan diadakannya vaksinasi masal di beberapa daerah seperti Inggris dan Amerika Serikat membuat kebijakan pengetatan protokol kesehatan menjadi dikurangi. Misal di negara Amerika Serikat yang sudah memperbolehan warganya untuk melepas masker atau berkegiatan tanpa masker, sedangkan di Inggris kegiatan publik sudah dapat dipenuhi oleh masyarakat. Hal ini dikarenakan hampir keseluruhan warga negara tersebut telah mendapatkan vaksin virus Covid-19 sehingga dapat membantu mengurangi penyebaran dan penambahan kasus jumlah positif virus tersebut. Dapat dikatakan kedua negara itu sudah menjalani pola kehidupan yang seperti biasanya untuk dijalankan mulai dari kegiatan pendidikan, perkantoran, perdagangan hingga pemanfaatan fasilitas umum lainnya.

Sementara itu tingkat penyebaran virus di Indonesia berbanding terbalik dengan yang terjadi di kedua negara tersebut. Hingga saat ini Indonesia masih terus bergelut dengan berbagai upaya untuk menurunkan jumlah kasus dan penyebaran virus Covid-19. Program vaksinasi masal juga tengah dilakukan oleh pemerintah Indonesia, meskipun masih belum seluruhnya mendapatkan vaksin itu. Banyak kendala yang ditemui oleh pemerintah Indonesia dalam penyuksesan program vaksinasi masal, diantaranya jumlah masyarakat Indonesia yang sangat banyak yang berbanding terbalik dengan jumlah dosis vaksin yang masih tersedia, selain itu masih ada beberapa masyarakat yang tidak percaya dengan kehadiran virus Covid-19 dan mempertanyakan keabsahan atau kehalalan dari vaksi-vaksin tersebut. Sehingga protokol kesehatan masih terus dilaksanakan di berbagai daerah di wilayah Indonesia untuk mengurangi jumlah penyebaran virus. Kebersihan lingkungan juga harus diterapkan untuk mengurangi penyebaran virus ini dengan meggerakan seluruh warga masyarakat agar sadar kebersihan dan kesehatan lingkungan sera mampu dengan baik dan benar mengelola sampah (Sunarsi, 2019). Hal ini membuat suatu lingkungan mampu menerapkan 3R (Reduce, Recycle, Reuse) dan menjadikan lingkungan yang berkelanjutan.

Sambil proses program vaksin masal berjalan terus sampai kepada seluruh warga Indonesia, herd immunity secara tidak langsung tengah dilaksanakan di Indonesia, dimana masyarakat harus bisa hidup berdampingan dengan virus Covid-19 yang sudah mulai menyebar dengan cepat dari human-to-human. Pembatasan sosial manusia sangat gencar dilaksanakan oleh pemerintah pusat dan daerah guna mengurangi penyebaran virus ini. Kegiatan pembatasan diutamakan dan diterapkan untuk beberapa wilayah khsusnya di Pulau Jawa dan Bali. Pada kedua pulau ini selain memiliki jumlah penduduk yang padat di beberapa wilayahnya, juga memiliki jumlah penambahan penambahan kasus positif dan meninggal virus Covid-19 yang sangat tinggi. PPKM (Pemberlakuan Pembatasan Kegiatan Masyarakat) darurat menjadi tambahan program pemerintah pusat untuk mengurangi kegiatan dan aktivitas warga masyarakat. Pada program ini seluruh faktor pendidikan harus berjalan dengan sistem daring/onlie, faktor perkantoran yang non esensial dipastikan bekerja secara WFH (Work From Home) sementara yang esensial hanya berlaku $25 \%-50 \%$ yang diperbolehkan masuk secara WFO (Work From Office), pasar/supermarket boleh buka namun harus menerapkan protokol kesehatan secara ketat, tempat makan (restoran) dan kumpul (kafe) hanya menerima secara take away/pesan antar dan tidak diperbolehkan makan ditempat, dan pusat perbelanjaan/mall harus sepenuhnya tutup total kecuali kios-kios F\&B (Food and Beverage) yang boleh buka namun tetap dengan sistem pesan antar.

Faktor pola hidup terkait kebersihan diri dan lingkungan juga harus selalu diperhatikan untuk mencegah dari penyebaran virus Covid-19 ini. Sebaiknya sebelum memulai segala sesuatu hendaknya tubuh kita harus hygiene dengan cara cuci tangan sebelum makan dan menggunakan handsanitizer agar tidak tertular berbagai jenis virus (Ningsih, 2014). Terlebih pada saat pandemi penyebaran virus Covid-19 ini yang sangat dituntut untuk hidup bersih dalam segala hal. PHBS (Perilaku Hidup Bersih dan Sehat) harus selalu diterapkan untuk memberikan kesadaran akan pentingnya hidup bersih dalam lingkungan masyarakat yang dimulai dari dalam keluarga kita hingga masyarakat secara luas (Patilaiya, 2018).Kota Surabaya menjadi salah 
satu daerah yang tingkat penambahan kasus positif dan meninggal akibat virus Covid-19 ini terus bertambah di tiap harinya. Hal ini membuat kekhawatiran bagi sebagian warga Kota Surabaya, sehingga pemerintah daerah menerapkan program PPKM Darurat ini dengan sangat ketat dan diawasi. Fungsi dari terlaksananya PPKM Darurat ini diharapkan jumlah kasus dan meninggal akibat virus ini mengalami penurunan dari waktu ke waktu, sehingga aktivitas masyarakat dapat berjalan dengan normal lagi meskipun masih harus menerapkan protokol kesehatan dengan sangat ketat. Apabila semua hal ini tercapai maka, pelonggaran untuk beberapa aktivitas masyarakat boleh diterapkan secara bertahap. Saat ini banyak warga kota dengan gangguan ringan lebih memilih melakukan isolasi mandiri di rumah masing-masing atau di beberapa penginapan yang mengijinkan. Sementara orang dengan gejala sedang banyak yang melakukan isolasi di beberapa tempat yang sudah disediakan pemerintah Kota Surabaya seperti gedung lapangan tembak dan asrama haji. Lalu untuk warga masyarakat Kota Surabaya dengn gangguan tinggi harus dirujuk dan diisolasi di rumah sakit untuk mendapatkan pantauan intensif dari dokter dan tenaga kesehatan lainnya. Selain itu PPKM Darurat ini digerakan diakibatkan karena jumlah pasien yang meningkat di beberapa wilayah di rumah sakit, sehingga rumah sakit mengalami penuh/over capacity dan mengakibatkan rumah sakit tidak bisa menerima lagi pasien dengan status terpapar virus Covid-19. Untuk itu pencegahan menjadi yang utama bagi seluruh warga masyarakat Kota Surabaya agar tidak terpapar virus Covid-19.

\section{Metode}

Kegiatan pengabdian kepada masyarakat terkait penyuluhan kepada warga di daerah Villa Kalijudan Indah Surabaya akan berlangsung dari bulan Februari 2021 sampai dengan Juni 2021. Metode pelaksanaan pengabdian kepada masyarakat kali ini menggunakan metode analisa sosial secara deskriptif kualitatif. Kegiata pengabdian kepada masyarakat dalam rangka KKN dosen dengan mahasiswa memiliki diagaram alur sebagai berikut:

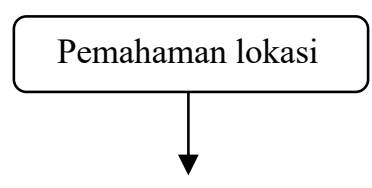

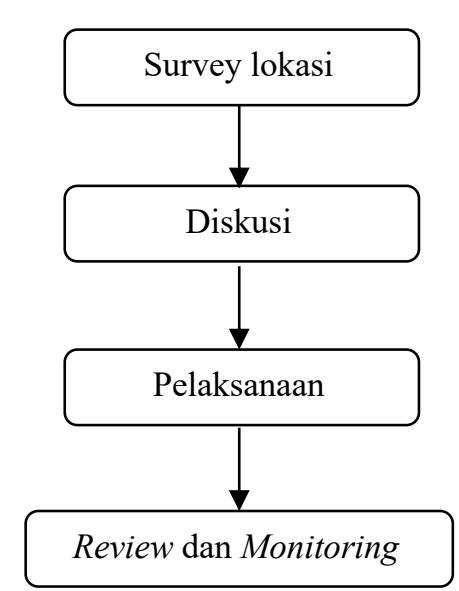

Gambar 1. Diagram alur pengabdian

Tahap awal yang dilakukan yaitu dengan bertemu dengan ketua RT setempat untuk menanyakan apa saja kegiatan yang dapat dilakukan di area ini. Harapan dari kedua pihak yaitu adanya kegiatan KKN oleh mahasiswa Universitas Katolik Darma Cendika yang mampu memberikan dampak perubahan besar dalam penanganan pandemi Covid-19, terutama di lingkungan ini. Adapun tahapan secara rinci dalam kegiatan KKN kali ini yaitu:

\section{a. Pemahaman akan lokasi yang telah dipilih}

Penentuan lokasi dipilih berdasarkan dari daerah beberapa mahasiswa yang disesuaikan dengan area tempat tinggalnya,

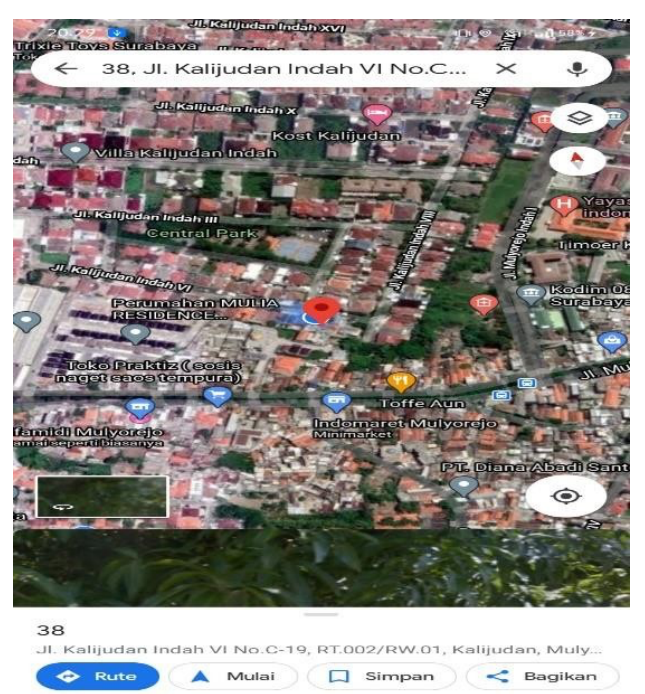

Gambar 2. Lokasi kegiatan pengabdian masyarakat

hal ini dikarenakan adanya pandemi yang menjadi batasan dalam berkegiatan 
pengabdian kepada masyarakat. Sehingga pemilihan lokasipun masih belum bisa secara bebas atau sesuai yang sangat membutuhkan. Lokasi yang diambil dan telah disepakati bersama yaitu di perumahan Villa Kalijudan Indah.

\section{b. Studi lapangan (survey lokasi)}

Peninjauan lapangan harus dilakukan terlebih dahulu setelah dilakukan tahap penentuan dan pemahaman lokasi terpilih. Tahap ini mahasiswa KKN melakukan proses pencatatan sementara aspek atau kegiatan apa saja yang nantinya dapat dilaksanakan di daerah ini. Dalam proses pengamatan lapangan awal perlu diperhatikan pula situasi dan kondisi sekitar agar program yang telah disusun dapat terlaksana dengan baik. Selain itu tim pegabdian masyarakat wajib menemui dan meminta ijin kepada ketua RT setempat terkait kegiatan pengabdian kepada masyarakat yang akan dilakukan diwilayah tersebut.

c. Diskusi bersama Ketua RT setempat dengan metode analisa sosial

Membuat agenda khusus pertemuan dengan pihak Ketua RT untuk melakukan diskusi tanya jawab dan bentuk wawancara untuk mendapatkan masukan dan pendapat dari pihak tersebut. Diskusi dilakukan antara tim kegiatan pengabdian masyarakat dalam bentuk KKN yang dilakukan oleh mahasiswa dengan Ketua RT yang kemudian dilakukan analisa sosial terkait kegiatan apa saja yang dimungkinkan dan dapat dilakukan dalam upaya penanggulangan pandemi virus Covid-19. Dari beberapa unsur kegiatan yang didiskusikan didapatkan beberapa poin yang telah dicatat dan nantinya disimpulkan bersama kegiatan apa saja yang akhirnya dipilih.

\section{d. Pelaksanaan pengabdian kepada masyarakat}

Kegiatan penyuluhan dalam kaitannya cara penanganan pandemi Covid-19 kepada masyarakat di lingkungan Villa Kalijudan Indah dipilih sebagai aktivitas utama dalam kegiatan pengabdian kepada masyarakat dalam bentuk KKN. Sehingga tim pengabdian nantinya akan mempersiapkan dan berkoordinasi bersama Ketua RT setempat untuk detail pelaksanaan kegiatan tersebut. Mulai dari waktu, peralatan atau perlengkapan apa saja yang dibutuhkan, undangan masyarakat yang terbatas dan topik penyuluhan yang akan disampaikan oleh tim pengabdian kepada masyarakat. Setidaknya segala persiapan harus segera terpenuhi seluruhnya sebelum waktu pelaksanaan yang telah ditetapkan bersama. Kegiatan ini akan berlangsung dari bulan Februari 2021 hingga Juni 2021, sehingga pelaksanaannya akan dilakukan dalam beberapa tahap, hal ini dilakukan agar penyuluhan dapat diperoleh secara merata kepada warga Villa Kalijudan Indah.

\section{e. Review dan monitoring seluruh kegiatan}

Penyuluhan kepada warga di lingkungan Villa Kalijudan Indah Surabaya ini menjadi kegiatan utama dalam pelaksanaan pengabdian kepada masyarakat, sehingga perlu diperhatikan dampaknya pasca pelaksanaan kegiatan tersebut. Tahap akhir ini perlu adanya review dan monitoring antara tim pengabdian dengan pihak Ketua RT setempat. Review dilakukan dimana tim mendapatkan saran dari pihak warga masyarakat setempat yang ikut penyuluhan bersama Ketua RT terkait proses kegiatan yang telah dilakukan, mencari kelemahan dan kekurangan selama kegiatan ini dilakukan serta kelanjutan kegiatan yang bisa dikembangkan dan dilakukan lagi kedepannya. Monitoring dilakukan tim pengabdian dengan cara memantau terus aktivitas warga secara berkala terkait kemajuan dan perkembangan dari kegiatan penyuluhan ini. Dapat berupa data yang dilakukan tiap waktu bersamaan dengan Ketua RT sebagai fasilitatornya mengenai perkembangan pencegahan kasus penyebaran virus Covid-19.

\section{Hasil Dan Pembahasan}

Penyebaran virus Covid-19 dengan varian Delta yang terus meluas jangkauannya membuat kekhawatiran diseluruh warga masyarakat di Kota Surabaya. Segala bentuk upaya pemerintah pusat dan daerah untuk menekan akan penyebaran dan peningkatan kasus positif virus ini dengan cara menerapkan 
PPKM yang harus dilaksanakan secara maksimal. Penerapan program ini sendiri diantaranya dengan membatasi aktivitas masyarakat diluar rumah seperti batasan kegiatan yang hanya diperbolehkan hingga pukul 20.00, sementara pusat perbelanjaan (mall) tutup secara keseluruhan kecuali gerai Food \& Beverage yang diperbolehkan buka namun hanya dengan sistem take away dan pembatasan wilayah atau jalanjalan dengan cara penutupan secara total di beberapa titik di Kota Surabaya sehigga tidak ada kendaraan yang diperbolehkan melintas di jalan tersebut.

Untuk itu sebagai bentuk upaya peduli akan pencegahan virus ini, kegiatan pengabdian masyarakat dalam bentuk KKN yang dilakukan oleh tim secara garis besar memberikan penyuluhan kepada warga masyarakat yang bertempat tinggal di Villa Kalijudan Indah Surabaya. Diharapkan dengan adanya penyuluhan yang intens dan disiplin dilaksanakan oleh seluruh peserta penyuluhan dapat membantu mengurangi penyebaran dan penambahan kasus virus Covid-19. Saat ini sendiri saja banyak rumah sakit yang sampai menolak pasien dengan gejala atau bahkan sudah terkonfirmasi terkena virus ini, hal dikarenakan jumlah ruang atau bed yang sudah penuh (overload). Sehingga banyak warga masyarakat akhirnya memilih untuk melakukan isolasi mandiri (isoman) di rumah masing-masing atau di beberapa penginapan (guest house). Untuk itu diharapka semua warga masyarakat di wilayah Villa Kalijudan Indah pada khususnya harus mematuhi dan menerapkan protokol kesehatan dengan sangat ketat. Kegiatan penyuluhan mengenai protokol kesehatan dan sesuai dengan anjuran pemerintah yang disampaikan kepada warga masyarakat Villa Kalijudan Indah terdiri dari 5M diantaranya:

1. Memakai masker

2. Mencuci tangan menggunakan sabun

3. Menjaga jarak minimal 1 meter

4. Menghindari kerumunan

5. Membatasi mobilitas atau pergerakan aktivitas diluar rumah

Kegiatan penyuluhan ini berlangsung dari bulan Februari hingga bulan Juni di tahun 2021, pelaksanaan dilakukan dengan cara mengumpulkan beberapa warga masyarakat secara bertahap dari waktu ke waktu, hal ini untuk mengurangi kerumunan dan terbatasnya ruang karena adanya jaga jarak dalam berkegiatan. Penyuluhan suatu kegiatan yang didasarkan pada tingkat pendidikan seseorang dimana pada dasarnya mampu memberikan materi edukasi untuk peningkatan lingkungan rumah tinggal (Pratomo, 2011). Segala kegiatan dalam bentuk penyuluhan tentang kesehatan dapat mempengaruhi tingkat pengetahuan, perilaku dan praktek dalam hidup bersih (Kusumawardani, 2012). Proses izin, diskusi serta koordinasi awal kegiatan penyuluhan yang akan dilakukan oleh tim bersama dengan Ketua RT setempat dalam bentuk wawancara yang telah dipersiapkan jauh-jauh hari sebelum hari pelaksanaan dimulai.

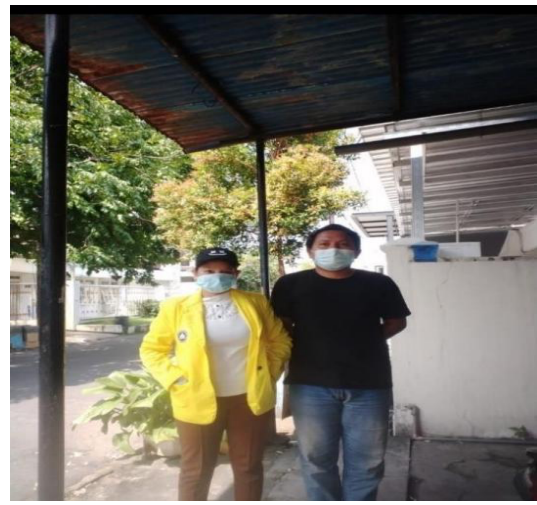

Gambar 3. Perwakilan mahasiswa izin dengan Ketua RT setempat

Melakukan pengumpulan warga masyarakat di lingkungan Villa Kalijudan Indah juga harus disertai dengan protokol kesehatan sebelum memasuki ruangan diantaranya cek suhu tubuh dan mencuci tangan dengan menggunakan sabun di air yang mengalir. Bila tidak ada gejala dari protokol kesehatan tersebut warga diperbolehkan masuk ruangan untuk mengikuti kegiatan penyuluhan ini. Sebelumnya undangan kepada beberapa warga di lakukan secara online agar mengurangi tatap muka dan bersentuhan secara langsung dan sesering mungkin. Penyuluhan mengenai kesehatan lingkungan dapat dilakukan ke semua umur tak terkecuali kepada siswa atau anak-anak yang diajarkan sejak dini sehingga mampu memberikan pemahaman akan kesehatan untuk meningkatkan pengetahuan (Hermawan, 2013). Warga masyarakat saat ini banyak yang berbondongbondong membeli dan menyimpan seluruh cairan kebersihan untuk sterilisasi diri terutama pada lingkungan rumah tinggalnya. Cairan sterilisasi itu dapat berupa desinfektan dan hand sanitizer, kedua benda ini biasanya digunakan pada tiap waktu terutama setelah bersiggungan dengan 
benda dan dengan orang orang lain. Kegiatan bersalaman dengan orang lain sementara ini masih dikurangi dan tidak dilakukan dulu untuk mencegah penyebaran virus Covid-19. Untuk mengurangi biaya pengeluaran yang besar dengan membeli beberapa cairan tersebut, saat ini banyak warga masyarakat yang meracik dan memproduksi sendiri sehingga campuranya dapat diatur sesuai keinginan dengan biaya yang dikeluarkan juga minim. Pembelian bahan baku utamanya pun dilakukan secara jumlah besar atau grosiran dan literan. Penyuluhan mengenai pemahaman dalam bidang kesehatan dapat berupa pelatihan dalam pembuatan hand sanitizer secara alami yang dapat dipraktekan oleh beberapa warga masyarakat sebagai kemampuan tambahan di massa pandemi ini (Munarsih, 2020). Warga masyarakat saat ini juga banyak mengkonsumsi vitamin dan antibiotik sebagai pencegahan penularan virus. Vitamin dan antibiotik saat ini mulai banyak dicari dan mengalami banyak peningkatan harga diberbagai apotek. Kedua benda ini diharapkan mampu meningkatkan imun tubuh agar tidak mudah tertular virus Covid-19. Penyuluhan dalam bentuk analisis mampu memberikan peningkatan pengetahuan dilingkungan masyarakat mengenai kegunaan vitamin dan antibiotik (Wowiling, 2013).

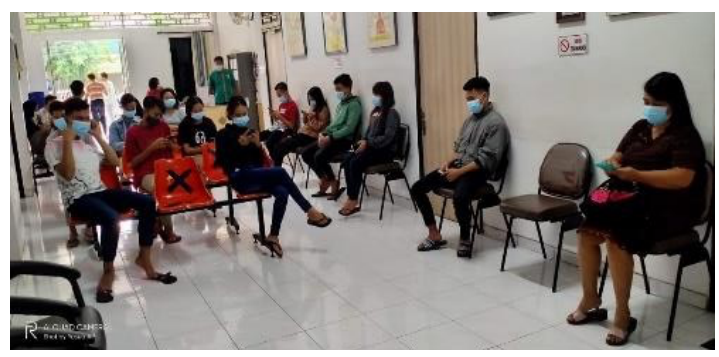

Gambar 4. Penyuluhan tim pengabdian masyarakat dengan masyarakat

Penyampaian penyuluhan dilakukan tim pengabdian masyarakat di Balai RT setempat yang dihadiri oleh Ketua RT dan beberapa warga masyarakat di lingkungan Villa Kalijudan Indah. Warga yang datang dilakukan secara bergelombang dan diatur harinya untuk mengurangi adanya penumpukan masa dalam suatu kegiatan dan ruang dengan menerapkan protokol kesehatan yang cukup ketat. Bila dilihat pada gambar 3, aktivitas duduk juga dilakukan dengan menjaga jarak. Penyuluhan disampaikan mengenai aktivitas protokol kesehatan $5 \mathrm{M}$ yang harus dilaksanakan dalam kehidupan sehari-hari apalagi masih banyak dan tingginya kasus positif virus Covid-19. Banyak masyarakat yang menginginkan adanya penyuluhan yang dikaitkan dengan topic keagamaan, pendidikan, dan kesehatan masyarakat dengan mengimplementasikan health behaviour melalui edukasi dan skrinning kesehatan (Arsyad, 2021). Pemahaman edukasi akan mencuci tangan dengan sabun di air yang mengalir dengan benar serta menggunakan cairan hand sanitizer kepada warga masyarakat yang dianggap efektif dan dapat menjadi pencegah dari penularan virus ini (Nurmiati, 2020).

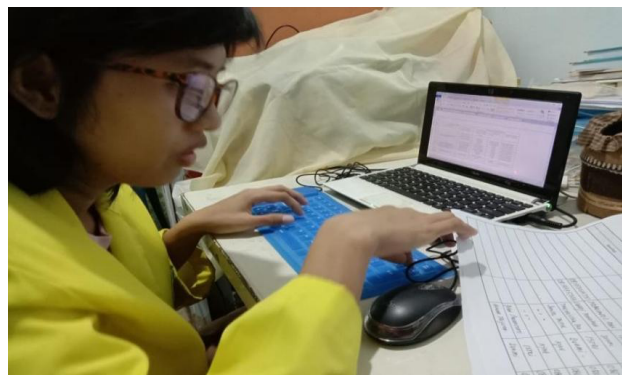

Gambar 5. Tim pengabdian melakukan pencatatan dan pendataan

Kegiatan penyuluhan kepada warga masyarakat Villa Kalijudan Indah berpusat pada pemberian edukasi mengenai kesehatan cara pencegahan dan penanganan dari virus Covid-19. Penyuluhan ini dalam satu kelompok warga dihadiri 20 orang yang disesuaikan dengan kapasitas ruang yang ada, dan semua dilakukan pencatatan data warga masyarakat yang datang ke lokasi. Monitoring menjadi cara yang dapat menjadi efektif untuk menekan penyebaran virus Covid-19 guna memberikan peningkatan kualitas kesehatan dan perekonomian di seluruh elemen masyarakat (Setiadiputra, 2020). Secara kodratnya manusia merupakan makhluk yang berjiwa sosial yang selalu bersosialisasi dan tidak dapat dipisahkan antara yang satu dengan lainnya (Putra, 2021).

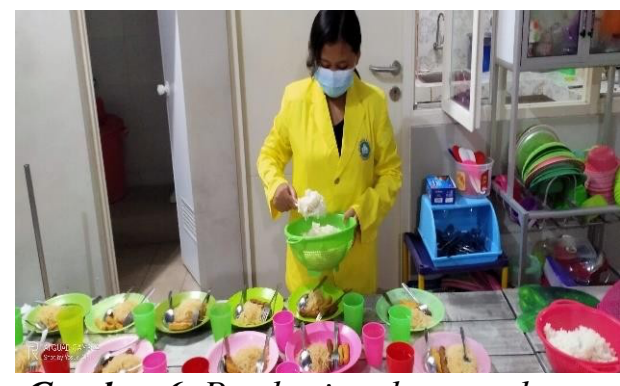

Gambar 6. Pemberian dan membantu penanganan konsumsi penyuluhan 
Dalam masyarakat tiap individu harus dapat hidup berdampingan dalam berbagai permasalahan tak terkecuali disaat pandemi Covid-19 ini. Saling kerja sama dan tolong menolong menjadi kunci utama dalam mengurangi hingga menghilangkan kasus Covid19 di Indonesia terlebih di Kota Surabaya. Penyuluhan akan pentingnya melaksanakan protokol kesehatan dan ikut andil dalam menyukseskan program vaksinasi pemerintah menjadi kegiatan utama saat ini untuk mengurangi jumlah penyebaran dan kematian akibat virus ini.

\section{Simpulan Dan Saran}

Penanganan pandemik Covid-19 yang melanda negara kita Indonesia harus kita perangi bersama terlebih di Kota Surabay terus mengalami peningkatan jumlah kasus terinfeksi dan meninggal dunia akibat virus ini. Penyuluhan harus sering diadakan kepada seluruh warga masyarakat terutama di Kota Surabaya terutama pada wilayah kegiatan pengabdian kepada masyarakat yang bertempat tinggal di Villa Kalijudan Indah. Pergerakan penyuluhan boleh digerakkan dari elemen warga masyarakat, pemerintah atau dinas terkait dan dari sektor pendidikan. Penyuluhan dalam bentuk KKN ini memberikan pengertian kepada warga masyarakat akan pentingnya menjaga protokol kesehatan 5M dengan sangat ketat dan wajib mematuhi peraturan PPKM pemerintah saat ini.

Selain itu program percepatan dan memaksimalkan vaksinasi untuk seluruh warga masyarakat terutama bagi warga Kota Surabaya menjadi program yang paling diutamakan. Vaksinasi diharapkan dapat mencegah dan mengurangi dampak kritis dari terpaparnya virus ini. Kelanjutannya dapat dilakukan secara berkala penyuluhan ini baik secara daring (dalam jaringan) ataupun secara luring (luar jaringan) yang dimana bila dilaksanakan secara luring harus disertai dengan protokol kesehatan sangat ketat. Sementara bila dilaksanakan secara daring dapat menggunakan platform meeting untuk melancarlkan kelanjutan program penyuluhan yang sudah dilakukan selama ini.

\section{Ucapan Terima Kasih}

Penulis dalam hal ini adalah tim pengabdian kepada masyarakat mengucapkan terima kasih kepada pihak yang mendukung dan ikut berpartisipasi dalam KKN ini baik secara moril ataupun materiil. Ucapan terima kasih juga kami berikan kepada LPPM Universitas Katolik Darma Cendika yang telah menjadi pemberi dana untuk terlaksananya program penyuluhan ini. Selain itu diucapkan pula kepada Ketua RT dan seluruh warga masyarakat di lingkungan Villa Kalijudan Indah yang mendukung dan turut serta dalam terlaksananya kegiatan ini guna menangani kasus virus Covid-19.

\section{Daftar Rujukan}

[1] Arsyad, K. \& Ramadhani, S. (2021). Implementasi Perilaku Sehat (Health Behaviour) dan Pemberdayaan Masyarakat dalam Bidang Pendidikan dan Keagamaan di Desa Mattampa Bulu. Jurnal LOSARI: Jurnal Pengabdian Kepada Masyarakat, 3(1), 26-32.

[2] Hermawan, Y. \& Ikhsan, KN. (2013). Pengaruh Penyuluhan Kesehatan Lingkungan Terhadap Tingkat Pengetahuan Dan Pelaksanaan Kesehatan Lingkungan SMP Negeri Tambaksari Kecamatan Tambaksati Kabupaten Ciamis. Jurnal Bumi Lestari, 13(1), 166-173.

[3] Kusumawardani, E. (2012). Pengaruh Penyuluhan Kesehatan Terhadap Tingkat Pengetahuan, Sikap Dan Praktik Ibu Dalam Pencegahan Demam Berdarah Dengue Pada Anak. Ujian Proposal Karya Tulis Ilmiah. Semarang.

[4] Munarsih, Savitri, SI., dkk. (2020). Penyuluhan Kesehatan Masyarakat Melalui Skill Training Antisipasi COVID-19 Dengan Busami (Pembuatan Handsanitizer Alami) Kelompok PKK di Kelurahan Sawah Ciputat. ABDI LAKSANA (Jurnal Pengabdian Kepada Masyarakat), 1(3), 368-373.

[5] Ningsih, R. (2014). Penyuluhan Hygiene Sanitasi Makanan Dan Minuman, Serta Kualitas Makanan Yang Dijajakan Pedagang Di Lingkungan SDN Kota Samarinda. Jurnal Kemas (Kesehatan Masyarakat), 10(1), 64-72.

[6] Nurmiati. \& Helvira, V. (2020). Penyuluhan Penggunaan Hand Sanitizer Dan Cuci Tangan Yang Benar. Jurnal LOSARI: Jurnal Pengabdian Kepada Masyarakat, 2(2), 3741. 
[7] Patilaiya, HL. \& Rahman, H. (2018). Pemberdayaan Masyarakat Melalui Penyuluhan Perilaku Hidup Bersih Dan Sehat Untuk Meningkatkan Kualitas Kesehatan Masyarakat. JPPM (Jurnal Pengabdian dan Pemberdayaan Masyarakat), 2(2), 251-258.

[9] Pratomo, S. (2011). Pengaruh Strategi Penyuluhan Dan Tingkat Pendidikan Terhadap Kepedulian Kesehatan Lingkungan. Jurnal Formatif, 1(2), 110128.

[10] Putra, HA. \& Roosandriantini, J. (2021). Pembentukan Ruang Bersama dan Ruang Terbuka Hijau di Lingkungan Babatan Pilang RT. 003 RW. 005. Abidumasy, 2(1), 31-39.

[11] Setiadiputra, RYP. (2020). Monitoring Pelaksanaan Pembatasan Sosial Berskala Besar Transisi di Pasar Tradisional Palmeriam Provinsi DKI Jakarta. Jurnal LOSARI: Jurnal Pengabdian Kepada Masyarakat, 2(2), 42-49.

[12] Sunarsi, D., Kustini, E., dkk. (2019). Penyuluhan Wirausaha Home Industry Untuk Meningkatkan Ekonomi Keluarga Dengan Daur Ulang Barang Bekas. Jurnal BAKTIMAS (Pengabdian Kepada Masyarakat), 1(4), 188-193.

[13] Wowiling, C., Goenawi, L.R., dan Citraningtyas, G. (2013). Pengaruh Penyuluhan Penggunaan Antibiotika Terhadap Tingkat Pengetahuan Masyarakat di Kota Manado. Jurnal PHARMACON (Jurnal Ilmiah Farmasi), 2(3), 24-28. 